\title{
HUBUNGAN STATUS NUTRISI DENGAN WAKTU PENYEMBUHAN LUKA PADA PASIEN POST APENDIKTOMI DI RUMAH SAKIT KOTA MEDAN
}

\author{
Muhammad Taufik Daniel Hasibuan \\ Dosen Prodi S1 Keperawatan, STIKes Murni Teguh, Jalan Jawa No 2 Gang Buntu Medan \\ E-mail: aniel.jibril@gmail.com
}

\begin{abstract}
ABSTRAK
Apendiktomi merupakan tindakan operasi yang dilakukan untuk menurunkan risiko perforasi pada kasus apendisitis. Perbaikan status nutrisi pada pasien dengan kasus pembedahan sangatlah penting untuk mempercepat proses penyembuhan luka. Penelitian ini bertujuan untuk mengetahui hubungan status nutrisi dengan waktu penyembuhan luka pada pasien post apendiktomi di rumah sakit kota Medan. Jenis penelitian ini adalah kuantitatif dengan design cross sectional. Sampel yang dipakai dalam penelitian ini berjumlah 18 orang dan teknik pengambilan sampel menggunakan metode non random sampling dengan accidental sampling. Pengumpulan data menggunakan kuisioner dan memakai index masa tubuh (IMT), dan analisa data menggunakan uji Chi Square. Dari hasil penelitian didapatkan hubungan status nutrisi dengan waktu penyembuhan luka, dengan derajat kemaknaan $(\alpha)$ 0,05 yaitu $X^{2}{ }_{\text {hitung. }} 4.114>X^{2}{ }_{\text {tabel }}$ : 3.841, p value : 0.01. Asupan nutrisi yang baik dapat menentukan waktu penyembuhan luka post apendiktomi. Diharapkan kepada petugas kesehatan memonitor status nutrisi pada pasien post operasi untuk dapat mengoptimalkan fase penyembuhan luka.
\end{abstract}

Kata kunci: Nutrisi, Luka, Apendiktomi

\section{ABSTRACT}

Appendictomy is an operation performed to reduce the risk of perforation in cases of appendicitis. Improvement of nutritional status in patients with surgery is very important to accelerate the wound healing process. This study aims to determine the relationship of nutritional status with wound healing time in post apendiktomi patient in Medan city hospital. This research type is quantitative with cross sectional design. The sample used in this study amounted to 18 people and the sampling technique using non-random sampling method with accidental sampling. Data collection using questionnaire and using body mass index (IMT), and data analysis using Chi Square test. From result of research got correlation of nutritional status with wound healing time, with degree of meaning ( $\alpha$ ) 0,05 that is $X^{2}$ hitung: $4.114>$ $X_{\text {tabel: }}^{2}$ 3.841, $p$ value: 0.01. Good nutrition intake can determine the wound healing time post apendiktomi. It is expected that health workers monitor the nutritional status of postoperative patients to optimize the wound healing phase.

Keywords: Nutrition, Wound, Appendictomy

\section{PENDAHULUAN}

Apendisitis merupakan bagian dari kasus kegawatan yang sering terjadi pada area abdomen. Apendisitis adalah suatu pen yakit prototype yang berlangsung melalui peradangan akibat obstruksi dan iskemia dengan gejala utamanya adalah nyeri yang mencerminkan dari keadaan penyakit (Mertha, 2013).

Menurut World Health Organization (WHO), insidena pendisitis di Negara maju lebih tinggi dari pada Negara berkembang, Amerika menangani 11 kasus/10.000 kasus apendisitis setiap tahun. Menurut data
RSPAD Gatot Subroto tahun 2008 jumlah pasien yang menderita penyakit apendisitis di Indonesia adalah sekitar 32\% dari jumlah populasi penduduk Indonesia. Menurut data dari Dinas Kesehatan Provinsi Sumatera Utara jumlah pasien yang menderita penyakit appendisitis yang melakukan operasi apendiktomi di Rumah Sakit Haji Adam Malik Medan tahun 2010 sebanyak 1.320 orang (Nainggolan dan Simanjuntak, 2013).

Menurut Jitowiyono dan Kristiyanasari (2012) apendiktomi dilakukan sesegera mungkin untuk menurunkan risiko perforasi pada kasus apendisitis. Didalam pasca pemb 
edahan, penanganan yang kurang baik rentan akan terjadi infeksi. Penanganan yang baik didalam melakukan manajemen luka akan mengurangi resiko komplikasi, dan apabila terjadi infeksi maka akan menyebabkan masa perawatan yang lebih lama, sehingga biaya perawatan di rumah sakit menjadi lebih tinggi (Puspitasari, 2011).

Waktu penyembuhan luka dapat ditentukan dengan membedakan dari jenis luka akut ataupun kronis. Apekdiktomi yang tidak mengalami infeksi pasca pembedahan termasuk kategori dari luka akut. Menurut Arisanty (2014), secara fisiologis luka akut akan sembuh \pm 0 -21 hari. Akan tetapi, jika pemberian nutrisi tidak terpenuhi dengan baik maka akan menghambat proses penyembuhan luka. Menurut Nainggolan dan Simanjuntak (2013) salah satu faktor yang mempengaruhi proses penyembuhan luka akibat operasi apekdiktomi adalah kurangnya asupan nutrisi.

Menurut Rusjiyanto (2009) berdasarkan data yang diperoleh lebihdari $50 \%$ pasien bedah yang dirawat lebih dari seminggu menderita anemia, mal nutrisi ataupun defisiensi vitamin. Hasil penelitian di Rumah Sakit Sardjito pada pasien bedah sekitar $52,46 \%$ pasien mengalami penyembuhan luka operasi lebih dari tujuh hari. Menurut teori penyembuhan luka operasi terjadi pada hari ketujuh yang merupakan fase terjadinya kola gen dan ditandai telah menyatunya jaringan kulit, tidak didapatkan tanda inflamasi dan pasien tidak lagi merasakan nyeri ditempat irisan operasinya. Pada penelitian lain di rumah sakit yang sama didapatkan bahwa dukungan nutrisi pada pasien bedah dapat menurunkan terjadinya komplikasi postoper asi.

Kekurangan asupan nutrisi pada pasien rawat inap adalah masalah yang sulit ditanggulangi. Masalah ini dapat terjadi dirumah sakit besar maupun kecil, ataupun dari negara maju maupun berkembang. Perbaikan status nutrisi pada pasien dengan kasus pembedahan sangatlah penting untuk mempercepat penyembuhan luka operasi dan penyakit dasarnya sendiri. Salah satu factor penyebab adanya permasalahan tersebut diantaranya karena pasien-pasien bedah di rumah sakit merupakan pasien yang rentan mal nutrisi, oleh karena itu intervene sinutrisi yang tepat pada pasien rawat inap dirumah sakit akan meningkatkan outcome klinik menuju kesembuhan, menurunkan komplikasi dan pada akhirnya menurunkan biaya rumah sakit (Rusjiyanto, 2009).

\section{METODE}

Jenis penelitian ini adalah kuantitatif dengan designcross sectional. Teknik pengambilan sampel menggunakan metode non random sampling dengan accidental sampling. Penelitian ini telah dilakukan di Murni Teguh Memorial Hospital pada bulan Januari-April 2018. Sampel yang dipakai dalam penelitian ini berjumlah 18 orang yang berstatus sebagai pasien rawat inap.

Pengambilan sampel mengguna kan metode non random sampling dengan accidental sampling. Pengumpulan data menggunakan kuisioner dan memakai perhitungan index masa tubuh (IMT), dan analisa data menggunakan uji Chi Square.

Terdapat 3 tahapan dalam proses pelaksanaan, yaitu 1) Tahap pertama : peneliti terlebih dahulu memberikan format data demografi untuk dapat diisi oleh responden, 2) Tahap kedua: peneliti mengajukan kuisioner dan mengukur status nutrisi responden menggunakan index masa tubuh (IMT): Tinggi Badan (TB), Berat Badan (BB), Haemoglobin (HB), dan pemantauan waktu penyembuhan, 3) Tahap ketiga: peneliti melakukan analisis data univ ariat dan bivariat dengan menghubungkan antara variabel independent dan variabel dependent dengan memakai distribusi frekuensi pada sistem komputerisasi.

\section{HASIL}

\section{Karakteristik Responden ( $\mathbf{N = 1 8})$}

Data demografi menunjukkan bahwa mayoritas usia responden berada pada usia 3 1- 40 tahun (33.3\%). Mayoritas jenis

kelamin responden adalah laki-laki $(61.1 \%)$. Mayoritas agama responden adalah islam $(55.6 \%)$. Mayoritas pendidikan respo 
nden adalah SLTA (55.6\%).Mayoritas pekerjaan responden adalah wiraswasta dan karyawan swasta $(44.4 \%)$.

\section{Hubungan Status Nutrisi Dengan Laman ya Waktu Penyembuhan Luka Pada Pasien Post Apendiktomi}

Dari hasil penelitian didapatkan hubung an yang signifikan antara status nutrisi dengan waktu penyembuhan luka pada pasien post apendiktomi, dengan derajat kemaknaan $(\alpha) 0,05$ yaitu $\mathrm{X}^{2}$ hitung: $4.114>$ $\mathrm{X}_{\text {tabel }}$ : 3.841, $p$ value : 0.01 .

Tabel 1. Distribusi Frekuensi, Persentase dan Uji Chi Square pada Status Nutrisi dengan Lamanya Waktu Penyembuhan Luka pada Pasien Post Apendiktomi( $\mathrm{N}=18)$

\begin{tabular}{|c|c|c|c|c|c|}
\hline \multirow{3}{*}{$\begin{array}{l}\text { Status } \\
\text { Nutrisi }\end{array}$} & \multicolumn{3}{|c|}{$\begin{array}{l}\text { Penyembuhan } \\
\text { Luka }\end{array}$} & \multicolumn{2}{|c|}{ Total } \\
\hline & \multicolumn{2}{|c|}{ Baik } & Buruk & \multirow[b]{2}{*}{$\mathbf{N}$} & \multirow[b]{2}{*}{$\%$} \\
\hline & $\mathbf{n}$ & $\%$ & n \% & & \\
\hline Terpenuhi & 13 & 86,7 & 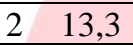 & 15 & 100 \\
\hline $\begin{array}{l}\text { Tidak } \\
\text { Terpenuhi }\end{array}$ & 1 & 33,3 & $2 \quad 66,7$ & 3 & 100 \\
\hline $\begin{array}{c}\mathrm{X}^{2} \\
\text { Hitung }\end{array}$ & & & & $\begin{array}{r}\mathbf{P} \\
\text { Valt }\end{array}$ & \\
\hline 4,114 & & & & 0,0 & \\
\hline
\end{tabular}

\section{PEMBAHASAN}

Dari hasil penelitian yang dilakukan peneliti dinyatakan bahwa didapatkan hubungan yang signifikan antara status nutrisi dengan waktu penyembuhan luka pada pasien post apendiktomi. Asupan nutrisi yang baik dapat menentukan waktu penyembuhan luka post apendiktomi. Nutrisi yang memiliki kandungan gizi terutama protein dapat membantu menumbuhkan jaringan yang rusak atau luka operasi Makanan atau nutrisi yang mudah ditemukan akan kandungan protein adalah putih telur. Putih telur kaya akan protein yang dapat menumbuhkan jaringan baru pada jaringan yang rusak.

Hasil penelitian ini diperkuat menurut Nainggolan dan Simanjuntak (2013), dimana dinyatakan bahwa faktor yang mempengaru hi proses penyembuhan luka apendik tomi adalah kurangnya asupan nutrisi dan kurangnya/ tidak melakukan mobilisasi dini.
Menurut Rusjiyanto (2009), pasien bedah yang menjalani rawat inap dirumah sakit rentan mengalami mal nutrisi, sehingga dapat menyebabkan hambatan pada waktu penyembuhan luka, oleh karena itu pemberian nutrisi yang tepat pada pasien rawat inap dirumah sakit akan meningkatkan kesembuhan, menurunkan komplikasi dan pada akhirnya menurunkan biaya rumah sakit.

Tindakan pembedahan akan menyebabk an stresfisiologis akibat hipermetabolisme.

Penatalaksanaan gizi dimaksudkan untuk mengurangi kehilangan gizi selama periode hipermetabolisme dan untuk mempromosikan perbaikan selama penyembuhan. Kebutuhan akan vitamin dan mineral seperti $\mathrm{Zn}$ dan vitamin $\mathrm{C}$ juga sangatlah penting untuk mendukung perbaikan jaringan pada $\mathrm{f}$ ase penyembuhan luka (Rusjiyanto, 2009).

\section{KESIMPULAN}

Kesimpulan hasil penelitian ini adalah

a. Terdapat hubungan yang signifikan antara status nutrisi dengan waktu penyembuhan luka pada pasien post apendiktomi.

b. Mayoritas usia responden berada pada usia31-40 tahun (33.3\%). Mayoritas jenis kelamin responden adalah lakilaki (61.1\%). Mayoritas agama responden adalah islam (55.6\%). Mayoritas pendidikan responden adalah SLTA (55.6\%). Mayoritas pekerjaan responde $\mathrm{n}$ adalah wiraswasta dan karyawan swasta $(44.4 \%)$.

\section{SARAN}

a. Rumah Sakit

Diharapkan kepada petugas kesehatan untuk memberikan pendidikan dan pelayanan yang optimal bagi pasien post operasi termasuk post apendiktomi dalam memenuhi nutrisi yang baik selama proses penyembuhan.

b. Bagi Pendidikan Keperawatan

Dari hasil penelitian ini diharapkan dapat menjadi informasi tambahan dan masukan dalam pengembangan pendidi kan keperawatan 
c. Bagi Peneliti Selanjutnya

Diharapkan bagi peneliti selanjutnya untuk menambah variabel lain untuk melihat faktor yang terkait terhadap proses penyembuhan luka

\section{DAFTAR PUSTAKA}

Arisanty, Irma P. (2014). Manajemen Perawatan Luka. Jakarta: EGC.

Jitowiyono, Sugeng dan Kristiyanasari, Weni. (2012). Asuhan Keperawatan

Post Operasi. Yogyakarta: Nuha Medika.

Mertha, I Made dan Arneliasih, Ni Wayan. (2013). Relaksasi Nafas dalam Terhadap Intensitas Nyeri pada Pasien Pre Apendiktomi. Jurnal Kesehatan Vol 1 No 2.
Nainggolan, Elfrida dan Simanjuntak, Lamria. (2013). Hubungan Mobilisasi Dini Dengan Lamanya Penyembuhan Luka Pasca Operasi Apendiktomi di Zaal C Rumah Sakit HKBP Balige Tahun 2013. Jurnal Keperawatan HKBP Balige Vol 1 No 2.

Puspitasari, Herlina Abriani. (2011). Faktorfaktor yang Mempengaruhi Penyembu han Luka Post Operasi Sectio Caesarea (SC). Jurnal Ilmu Kesehatan Keperawatan Vol 7 No 1.

Rusjianto. (2009). Pengaruh Pemberian Suplemen Seng (Zn) Dan Vitamin C Terhadap Kecepatan Penyembuhan Luka Pasca Bedah di Rumah Sakit Umum Daerah Kabupaten Sukoharjo. Jurnal Kedokteran Indonesia Vol 1 No 1. 